\title{
An empirical analysis of cultural ecosystem values in coastal landscapes
}

\begin{abstract}
Coastal areas are especially important to human well-being with half the world's population living within $60 \mathrm{~km}$ of the sea and three-quarters of all large cities located in the coastal zone. Supporting and regulatory ecosystem services in coastal areas have received considerable research attention given human vulnerability to climate change, but cultural ecosystem services in the coastal zone are less understood. This study describes and analyzes the distribution of cultural ecosystem values found in coastal areas in multiple countries $(n=5)$ and compares the results with non-coastal areas. Mapped cultural ecosystem values were collected from public participation GIS (PPGIS) processes in the U.S., Australia, New Zealand, Norway, and Malaysia and analyzed to identify the type and intensity of ecosystem values located in coastal areas. Mapped ecosystem values were significantly more abundant in all coastal zones, regardless of ecosystem value category, country, population, or dominant land use. Compared to cultural ecosystem values, biological and life-sustaining values were mapped less frequently in the coastal zone. Economic and social values were significantly associated with developed (built) coastal zones, while aesthetic and recreation values were more strongly associated with natural coastal zones. Coastal access, especially by road, influences the mix of perceived values from nature-based values to anthropocentric values. Coastal zones will continue to be the principle location for potential future land use conflict given their high social and cultural value relative to other ecological values. Understanding trade-offs in coastal zone planning and management requires a systematic inventory of the full range of ecosystem services, including cultural services.
\end{abstract}

Keywords: cultural values; coastal zone; PPGIS; participatory mapping; coastal development 


\section{Introduction}

Coastal ecosystems are among the most productive but threatened systems in the world,

31 producing disproportionately more services than most other systems (Agardy et al., 2005).

32 Further, coastal areas are especially important to human well-being with about half the world's

33 population living within $60 \mathrm{~km}$ of the sea and three-quarters of all large cities located in the coastal zone (UNEP, 2016). From an economic perspective, many of these coastal systems that provide important ecosystem services have yet to be valued reliably (Barbier et al., 2011; Brenner et al., 2010). While research on provisioning, regulatory, and supporting services of coastal ecosystems may be characterized as inadequate, information about cultural ecosystem services (CES) in the marine and coastal zone is even more limited, with little knowledge from developing countries, and with most studies implemented in Europe and North America (Martin et al., 2016). Socioeconomic data suggest that people living in coastal areas experience higher well-being than those living in inland areas (Agardy et al., 2005), but there has been little systematic empirical research to identify the distribution of cultural ecosystem services provided within the coastal zone relative to non-coastal zone areas. This is not surprising as the general study of CES has been one of most neglected and poorly integrated within the ecosystem services framework (Chan et al., 2012; Daniel et al., 2012; Schaich et al., 2010). This research seeks to address this knowledge gap by examining the distribution of cultural ecosystem services found in coastal zones in study areas located in five countries.

Cultural ecosystem services (CES) are the nonmaterial benefits people obtain from ecosystems through spiritual enrichment, cognitive development, reflection, recreation, and aesthetic experiences (MEA, 2005). Cultural ecosystem services are considered intangible

51 (Milcu et al., 2013) with most indicators of cultural services deficient in clarity of definitions, 52 purposes and understanding, with relatively few indicators incorporating spatially explicit 53 information (Hernández-Morcillo et al., 2013). Most CES are not directly observable in the

54 physical landscape and require either proxy or indicator measures (see e.g., Raudsepp-Hearne et 55 al. 2010) or empirical research such as participatory mapping (Klain and Chan, 2012). A logical 56 consequence is that CES are rarely fully considered in ecosystem services assessments

57 (Plieninger et al., 2013) with poor integration with management plans (de Groot et al., 2010;

58 Arkema et al., 2015). 
Participatory mapping methods variously described as public participation GIS (PPGIS),

60 participatory GIS (PGIS), and volunteered geographic information (VGI) are suitable for the

61 identification and assessment of CES (see Brown and Fagerholm, 2015, for a review of methods

62 and applications). The terms PPGIS, PGIS, and VGI describe a range of participatory mapping

63 methods where spatial data collection and use is a core component of the process (see Brown and

64 Kyttä, 2014). As a social research method, participatory mapping identifies place attributes that

65 range from objective place features to subjective perceptions of place and importance, including

66 place attachment (Brown et al., 2015a). Participatory mapping is valid for identifying CES under

67 the assumption that place values identify locations that directly or indirectly provide services or

68 benefits to the participant. The terms ecosystem "service” and "value” are often conflated

69 because the terms are closely related. Ecosystem services are the benefits people obtain from

70 ecosystems. Ecosystem values are measures of how important ecosystem services are to people.

71 An assumption of participatory mapping is that when a place is identified as valuable, it provides

72 the mapped benefit or service such as scenery or recreation.

73 The mapping of CES can use variable methods where the types and locations of CES are

74 emergent in the data collection process, for example, using interviews or small group processes

75 (see Klain and Chan, 2012; Lowery and Morse, 2013; Rieprich and Schnegg, 2015) or through

76 the use of pre-defined CES categories where study participants identify locations on a hardcopy

77 or digital map. CES appear in "bundles" and their co-occurrence could be related to a range of

78 conditions, including biophysical features as well as socioeconomic characteristics (Klain and

79 Chan, 2012; Plieninger et al., 2013).

80 A number of typologies have been used to assess CES and many operationalize the

81 cultural services described in the MEA (2005). While most of the identified CES can be

82 accurately described as globally universal, the relative importance of CES can vary by

83 geographic location and population. Just as provisioning, supporting, and regulatory ecosystem

84 services are not spatially homogeneous, one would not expect CES to be spatially homogeneous

85 either. As pressures on the coastal zone increase, there is an urgent need for spatially explicit,

86 empirical assessments that can be directly used in coastal planning. As shown in a recent study

87 by Arkema et al. (2015), the integration of ecosystem services into coastal planning can provide

88 synergies and benefits for both nature and people. In that study, models were developed to

89 quantify the ecosystem services provided by corals, mangroves, and seagrasses in coastal Belize. 
90 Through an iterative process that included stakeholder engagement, a coastal plan was developed

91 that would result in greater coastal protection (nature benefits) and tourism (people benefits) than

92 would be achieved with either conservation or development goals in isolation.

\subsection{Coastal zone classification}

There is no standard definition for what constitutes a coastal zone, but functionally, the coastal zone is a spatial area that includes the landward limit of marine influence and the seaward

97 limit of terrestrial influence (Carter, 1988). Coastal zones are the interface where the land meets the ocean encompassing shoreline environments as well as adjacent coastal waters. This study is focused principally on the terrestrial or landward component of the coastal zone which includes both natural features such as river deltas, coastal plains, wetlands, beaches and dunes, mangrove forests, and lagoons, as well as artificial features associated with human development and

102 occupation such as ports, cities, rural housing, manufacturing, resorts, and agriculture. In the

103 absence of a standard definition for marine and terrestrial influence, the coastal zone is often

104 operationalized as a fixed distance from the coastline. In this study, we operationalize the coastal zone as distance bands ranging from the coastline to 3000 meters landward.

Coastal zones have been classified using a number of different systems that focus on physical and geomorphic characteristics. For example, the U.S. Geological Survey (USGS) provides a coastal classification system that accounts for both geomorphic features and human development to assist in coastal hazard assessment (USGS, 2014). Human development is

110 described by the density of development and the structure present while undeveloped areas are

111 described with physical descriptors such as beach scarp bluff, beach dune, and washover

112 complex. Coastal classification systems thus emphasize the physical structure over the cultural

113 services that are bundled with the physical features and there isn't a coastal classification system

114 that accounts for the cultural ecosystem values associated with the coastal zone. Although it

115 appears intuitive that there should be a relationship between the types of physical coastal features

116 and the associated cultural ecosystem values (e.g., beaches provide enhanced opportunities for

117 recreation and social interaction while coastal bluffs and escarpments provide scenery and

118 inspiration), there has be little study of these putative relationships. This comparative analysis

119 empirically explores the distribution of cultural values associated with the coastal zone. 


\section{$122 \quad 1.2$ Research aims}

123 The purpose of this research is to examine the spatial distribution of cultural ecosystem

124 values found within the coastal zone across diverse physical and social settings. The research

125 represents a type of comparative analysis to identify patterns in the global distribution of cultural 126 ecosystem services within coastal zones. As the first such coastal study, the research approach is

127 largely inductive and non-theory driven. However, there are a number of presuppositions that 128 can be derived from logical inference or previous cultural ecosystem values research. Given that 129 (1) coastal zones now comprise a disproportionate share of human settlement, (2) cultural 130 ecosystem services are linked to human activities and experiences, and (3) humans engage in 131 geographic or spatial discounting when mapping - identifying values closer to home, one would 132 expect higher proportions of cultural ecosystem values in coastal areas that are dominated by 133 human settlement. Does this presupposition also apply to coastal areas with relatively sparse 134 human settlement? If cultural ecosystem values are disproportionately greater in these latter coastal zones, what coastal attributes or features could account for these results?

Previous research found significant positive or negative spatial associations between

137 mapped cultural ecosystem values and global land cover classes such as forest cover, water, and agriculture (Brown, 2013), as well as landforms such as mountains, valleys, and lakes (Brown and Brabyn, 2012). Similarly, one would expect some empirical associations to be evident in the coastal zone, especially between natural land cover features and human-modified areas.

Another important variable in the coastal zone is access that facilitates coastal use and

143 significantly influence the mix of cultural ecosystem values found in the coastal zone (Brown 144 and Weber, 2012). In the wake of new coastal development on Kangaroo Island, South Australia, 145 the proportion of economic and recreation values increased while there were large, proportional 146 declines in intrinsic, spiritual, and therapeutic values (Brown and Weber, 2012).

147 Given these research aims, we sought answers to the following research questions:

148 1) How are cultural ecosystem values distributed in coastal zones and are these distributions 149 similar or different across diverse coastal landscapes and human populations? 
151

152 153

154

155

156

157

158

159

160

161

162

163

164

165

166

167

168

169

170

171

172

173

174

175

176

177

178

179

180

181

2) Is the observed distribution of specific cultural ecosystem values (e.g., scenic, recreation, spiritual) greater or less than expected relative to the population and area in the coastal zone?

3) What is the relationship, if any, between land use/cover in the coastal zone and the distribution of cultural ecosystem services?

4) How does coastal access and development influence the mix and distribution of ecosystem values found in the coastal zone?

5) What are the implications of the empirical findings for managing ecosystem services in the coastal zone?

\section{Methods}

\subsection{Study areas and data collection}

This study used participatory mapping data from five studies conducted between 2011 and 2015 in the countries of Australia, New Zealand, Malaysia, Norway, and the U.S. (Alaska)

(Figure 1). The study areas provide significant contrast in geographic setting, size, dominant land cover/land use, and population density (Table 1). The study areas include high latitude (Alaska/Norway), tropical (Malaysia), sub-tropical (Australia), and temperate regions (New Zealand). The study area sizes range from 38,836 km² (Alaska) to $823 \mathrm{~km}^{2}$ (Malaysia) with population densities ranging from less than $1 / \mathrm{km}^{2}$ (Alaska) to about 300/km² (Malaysia). The dominant land cover/land use ranges from natural (Alaska/Norway) to a mix of natural and human-modified (New Zealand, Australia), to agricultural (Malaysia).

\section{[Insert Figure 1]}

\section{[Insert Table 1]}

Participants mapped value locations in the study areas using a typology of ecosystem values that were tailored for each study. Four cultural ecosystem values were common to all five studies: aesthetic/scenic, recreation, economic, and cultural/historic value. Other cultural ecosystem values appeared in fewer than five studies: spiritual $(n=4)$, social $(n=3)$, learning 
$182(n=2)$, and therapeutic $(n=2)$. Three other ecosystem values that are more closely related to

183 supporting and regulatory ecosystem services were included in this analysis for comparison:

184 biological $(n=4)$, life sustaining $(n=3)$, and wild/pristine $(n=4)$. For a complete list of ecosystem

185 values used in each study, references are provided in Table 1.

186 The data was collected using an internet application with a Google ${ }^{\circledR}$ maps interface

187 where study participants were requested to drag and drop digital markers onto a map of the study

188 region to identify the locations of the ecosystem values. The mapping instructions were tailored

189 to each study, but generalized instructions were as follows: "Use the map markers on the left to

190 identify the places you value. Place as many (or few) markers on the map as you like. Click on a

191 marker and drag it to the relevant map location. Optionally click on marker after map placement

192 for a pop-up window to explain the marker.”

193 In four of the studies, participants were recruited via mail through random sampling of

194 households. Participants were provided with the URL of the website for self-administration with

195 the exception of the Malaysia study where participants were recruited through personal contact

196 and mapping was completed on a laptop computer in the presence of a facilitator. Sample sizes

197 across the five studies ranged from 244 to 440 participants.

\subsection{Spatial data preparation}

200 The coastal zone was operationalized as a landward distance from the coastline in each of 201 the five study areas. Using GIS software, distance bands were generated for 500, 1000, 2000, and 2023000 meters. The mapped ecosystem value points were spatially intersected with the distance 203 bands to generate frequency distributions for each band. To determine whether ecosystem values 204 were distributed proportionally by area in the distance bands, we calculated area using ArcGIS 205 (Ver. 10.3) software. To determine whether ecosystem values were proportional to the 206 population living in each distance band, we estimated the population using data from the gridded 207 population of the world (GPW), version 4, UN-adjusted population counts for 2015 (CIESIN, 208 2015). To identify ecosystem values by land use/land cover, we spatially intersected the 209 ecosystem value points with a global land cover data database (GlobCover) developed by the 210 European Space Agency in collaboration with the Université Catholique de Louvain (Bontemps 211 et al., 2011). GlobCover has a spatial resolution of 300 m, 22 land cover classes, and an overall 212 accuracy weighted by class area of 67.5\% (Bontemps et al., 2011, p. 47). 
2142.3 Analyses

215 2.3.1 Distribution of ecosystem values in coastal and non-coastal areas

216 We examined the distribution of ecosystem values in coastal and non-coastal zones using

217 multiple distance bands from the coastline-500, 1000, 2000, and 3000 meters. To determine

218 whether specific values were more or less abundant in coastal versus non-coastal zones, we used

219 two methods-proportional analysis and independence analysis. Proportional analysis assumes

220 that mapped ecosystem values should be distributed proportionately based on the fractional

221 proportion of the study area occupied by the coastal zone or by the fractional proportion of the

222 population living in the study region. For example, if the coastal zone represents 10 percent of

223 the study area, 10 percent of the ecosystem values would be expected in the coastal zone.

224 Similarly, if the coastal zone represents 10 percent of the study region population, 10 percent of

225 the ecosystem values would be expected in the coastal zone. We calculated the proportion of

226 ecosystem values mapped in each distance band and plotted these to visually show the observed

227 versus expected proportions as function of distance from the coastline. For the distance band of

2281000 meters, we calculated z scores to determine whether the observed/expected proportional

229 differences were statistically significant using a one-sample proportion test. Z scores greater than

$230+2.0$ indicate a higher proportion of mapping values than expected, while $\mathrm{z}$ scores less than -2.0

231 indicate fewer mapped values than expected.

232 In the independence analysis, we generated cross-tabulations, chi-square statistics, and

233 standardized residuals to examine the distribution of mapped ecosystem values within 1000

234 meters of the coastline compared to values outside coastal zone. This is a type of

235 presence/absence analysis that assumes values mapped in the coastal zone are independent of

236 values mapped outside the coastal zone (i.e., there is no association). Following a significant chi-

237 square result, standardized residuals were calculated for each ecosystem value to determine

238 whether the number of mapped values was significantly different from expected counts in the

239 coastal zone. Expected counts are the projected point frequencies in the coastal zone if the null

240 hypothesis is true, i.e., the distribution of mapped values are independent of the coastal zone.

241 Standardized residuals greater than +2.0 indicate a given value is over-represented in the coastal

242 zone while scores less than -2.0 indicate the value is significantly under-represented in the

243 coastal zone. 
2.3.2 Distribution of ecosystems values by coastal land cover

This analysis examined whether the type of ecosystem value was more or less abundant

247 in natural versus human-modified coastal environments. Human modified environments were

248 GlobCover classes identified as artificial development (class 190) or agriculture (classes 11, 14,

24920 and 30). We examined the distribution of ecosystem values associated with human modified

250 coastal environments at multiple distance bands from the coastline-500, 1000, 2000, and 3000

251 meters. We calculated chi-square statistics to determine whether ecosystem values were

252 independent of land use/land cover, and following a significant association, standardized

253 residuals to determine which specific ecosystem values were over- or under-represented in

254 human-modified coastal areas. This type of land use comparative analysis was meaningful for

255 three of the five study areas. The coastal zone in the Alaska study did not contain any significant

256 area of artificial development while the coastal zone in Malaysia did not contain any significant

257 natural areas.

\subsubsection{Distribution of ecosystem values by coastal access and development}

260 We examined the distribution of ecosystem values associated with coastal access and

261 development by plotting the spatial location of ecosystem values presumed to be associated with

262 coastal development and road access (e.g., economic and social values) with ecosystem values

263 associated with more natural landscapes (e.g., biological and life sustaining values). Maps were

264 generated for all five coastal areas showing the spatial distribution of these contrasting types of

265 ecosystem values.

\subsubsection{Distribution of ecosystem values by country}

268 To examine similarities and differences in the distribution of ecosystem values by 269 country, we computed the proportion of each value mapped within the multiple distance bands 270 from the coastline-500, 1000, 2000, and 3000 meters. We tested for statistically significant

271 differences by country in the proportions within the distance bands using a $\mathrm{z}$ test with Bonferroni 272 adjustments for multiple comparisons. 
275

276

277

278

279

280

281

282

283

284

285

286

287

288

289

290

291

292

293

\section{4 [Insert Figures 2 and 3]}

295

296

297

298

299

300

301

302

303

304

305

\section{Results} exception of recreation value.

\subsection{Distribution of ecosystem values by distance from coast}

The proportions of mapped ecosystem values in the coastal zone were greater in all five study areas than would be expected for all distance bands from the coastline (see Figure 2). Ecosystem values were disproportionately greater based on both area and population criteria as indicated by the observed proportion of ecosystem values (lines) plotted above the expected proportion (solid area) by area and population in Figure 2. Of the five study areas, mapped ecosystem values in Australia and Malaysia showed the largest deviations from expected area and population proportions in the coastal zone across all ecosystem value types, while the least proportional differences were found in Alaska and Norway. Cultural and heritage proportions in the coastal zone were largest in Alaska and New Zealand, while aesthetic/scenic values were largest in Australia and Malaysia. The distribution of social values had the largest deviation from expected proportions in Norway. The statistical significance of these proportional differences by area was examined within a 1000 meter coastal zone. $Z$ scores were greater than +2.0 for the large majority of ecosystem values across all five study areas (See Figure 3) with most z scores exceeding five. The proportional distribution of nature-related ecosystem services (biological, life sustaining, and wild/pristine) were variable across the five study areas, with Australia having the largest proportions of these types of values in the coastal zone.

The chi-square analyses confirmed that the distribution of ecosystem values was significantly associated with coastal locations, with standardized residuals showing variability by type of ecosystem value (see Figure 4). Whereas the proportional analysis revealed significantly higher proportions for most ecosystem values in the coastal zone by area or population, chisquare analysis examined the distribution of values relative to the proportion of other values mapped in the study. Under these conditions, the standardized residuals indicate that recreation value was significantly under-represented in the coastal zone in Alaska and Norway relative to other values, but over-represented in Australia. The Norway study area had the largest deviation of observed cultural ecosystem values from expected counts for all cultural values with the 
[Insert Figure 4]

\subsection{Distribution of ecosystem values by land use/land cover}

We examined whether the distribution of ecosystem values was related to the type of land use/land cover located within the coastal zone with a focus on natural versus human-modified areas. In Norway and Australia, the proportion of all mapped ecosystem values of any type was greater than expected in human-modified coastal areas (see Table 2), while mapped values in

314 New Zealand approximated the expected distribution in human-modified areas. This land 315 use/land cover analysis was not meaningful for Alaska and Malaysia which were dominated by 316 natural and developed coastal areas respectively. Chi-square and residuals analysis indicated that 317 economic and social values were over-represented in developed coastal areas in Norway and 318 Australia, while biological values were under-represented in developed areas in Australia. Thus, 319 economic and social values were more concentrated in areas of human development in the 320 coastal zone.

\section{2 [Insert Table 2]}

\subsection{Distribution of ecosystem values by coastal development and road access}

Ecosystem values principally associated with coastal development were plotted for comparison with more nature-based ecosystem values in the five study areas. See Figure 5 . The influence of coastal development and access on the distribution of ecosystem values varied by

328 study area. In New Zealand (Figure 5a), the western reach of the coastal zone is located in 329 Fiordland National Park, a rugged, mountainous region where road access is limited to a single 330 location at Milford Sound. Nature-based ecosystem values dominate the coastal zone with the 331 exception of Milford Sound. Economic and social values were more abundant in the southern 332 coastal zone which is road accessible with greater levels of development, including the city of Invercargill. In Alaska (Figure 5e), the coastal zone in Prince William Sound is inaccessible by 334 road with the exception of the town of Whittier, a primary access point for tourism activities (i.e., 335 economic value). The economic values radiate from Whittier to coastal areas accessible by boat. In Malaysia (Figure 5c), economic and development values were highly clustered near the town 
337 of Kuala Perlis. The southern reach of the coastal zone is road accessible, but is characterized by agricultural activity and sparse human settlement. In Norway (Figure 5d), economic and social values in the coastal zone were distributed based on the locations of towns and villages, the largest settlement being Bodo. Significant clusters of values also exist at Sør Arnøy, a fishing village and island, and Fauske, a town with economic activities associated with hydroelectric power, quarries, and tourism. In Australia (Figure 5b), economic and social values were mixed with nature-based values in the coastal zone between the communities of Agnes Waters in the north and Rules Beach in the South. This stretch of the coastal zone is generally accessible by road. The northern reach of the coastal zone is less accessible by road and nature-based values dominate. A significant cluster of both economic/social and nature-based values were located near Rules Beach at the mouth of Baffle Creek, a popular fishing and recreation destination.

[Insert Figure 5]

\subsection{Distribution of ecosystem values by country}

We assessed similarities and differences in the distribution of ecosystem values by country using proportional tests in multiple distance bands from the coastline. The results appear in Table 3. Alaska, Malaysia, and Norway were most similar in the distribution of aesthetic and recreation values in the coastal zone, while Australia and New Zealand were the most different, with Australia having disproportionately more values and New Zealand having disproportionately fewer values. Malaysia was unique in having disproportionately fewer economic, social, and spiritual values mapped in the coastal zone in all distance bands. With respect to mapped biological values, Alaska and Norway had similar distributions, but differed

360 from Australia (proportionately more values) and Malaysia (proportionately fewer values). In

361 the mapping of wild/pristine values, Australia and Alaska were similar with disproportionately

362 more mapped values than New Zealand and Norway. Generalizing across all ecosystem value

363 categories, Alaska and Norway were most similar in the distribution of coastal ecosystem values, 364 while Malaysia was most unique with fewer mapped values. 


\section{Discussion}

This comparative analysis has shown that coastal areas contain a disproportionate share of cultural ecosystem values compared to non-coastal areas across a diverse range of geographic locations, from natural landscapes (Alaska, Norway), to heavily human-modified (Malaysia), to

372 mixed landscapes (Australia, New Zealand). These findings are consistent with earlier, nonparticipatory mapping studies from Denmark and the United Kingdom that also found high provision of cultural services in coastal areas (Norton et al., 2012; Turner et al., 2014). Coastal areas are globally recognized for their scenic and recreation values in particular, but the geographic location provides contextual nuance. In the higher latitude coastal areas of Alaska, Norway, and New Zealand, recreation values were proportionately more abundant, but underrepresented relative to recreation values mapped in non-coastal areas. These three study areas, with their remarkable mountain terrain, provide exceptional non-coastal recreation opportunities. In contrast, coastal areas in Australia and Malaysia are principal sources of regional recreation and scenic values.

Coastal areas were recognized for other cultural ecosystem values including economic, culture/heritage, social, and spiritual value. Economic and social values were more strongly associated with artificial rather than natural areas in the coastal zone. Road access, in particular, influences the mix of perceived values in the coastal zone toward values most closely aligned with the built environment. The non-cultural values mapped in the studies-biological and lifesustaining-were disproportionately abundant in coastal areas, but under-represented relative to other mapped cultural ecosystem values.

What are the applied implications of these findings? Brown and Raymond (2014) proposed a land use conflict model wherein potential conflict derives from differences in land use preferences (what is appropriate use?) and values (what is important?) in place-specific locations. Differences in land use preferences are magnified by the quantity of place values with more mapped values indicating higher potential for conflict. Given the greater abundance and importance of cultural ecosystem values in coastal areas, the potential for conflict appears greater than for non-coastal areas. However, conflict is not inevitable with the mere presence of more mapped ecosystem values in the coastal zone. Spatial zoning can serve to separate conflicting

397 land uses while clustering compatible values. The concept of integrated coastal zone management (ICZM), for example, acknowledges the presence of multiple and sometimes 
conflicting uses and values and seeks "to balance environmental, economic, social, cultural and

400 recreational objectives, all within the limits set by natural dynamics” (COM, 2000). While spatial

401 zoning is an important tool for coastal management, coastal areas are increasingly confronted

402 with capacity constraints from pressure from human development combined with concurrent loss

403 or degradation in ecological function resulting from climate change. In what could become a

404 type of ecosystem services triage in coastal areas, should we prioritize cultural ecosystem values

405 such as recreation associated with beaches, economic and social values associated with human

406 development, or biological and life sustaining values associated with natural coastal features?

407 There are no simple solutions for balancing the multiple and often conflicting objectives for

408 coastal management, but understanding trade-offs begins with a systematic inventory of the full

409 range of ecosystem services, including cultural services, provided in the coastal zone.

410 The associations between ecosystem values and coastal features provide some general

411 guidance for the types of values that are at risk from changes in the physical coastal

412 environment. Cultural ecosystem values appear "bundled” (Raudsepp-Hearne et al., 2010) or

413 exhibit “synergies” (De Vreese et al., 2016) in place-specific locations associated with physical

414 features. For example, in the case of Australia, the loss of beaches to erosion could reduce

415 multiple cultural values including recreation, scenic, economic, and social values. And if tidal

416 deltas and intertidal areas were degraded, not only would biological and life sustaining services

417 be compromised, the cultural ecosystem values of recreation, scenery, and learning could be

418 adversely affected.

419 Our results also indicate that coastal access, especially by road, are related to the

420 distribution of ecosystem values. Road access and development are often closely related and can

421 change the mix of mapped values from nature-based values to social and economic values.

422 Across the five study areas, there were some examples of spatial mixing of nature-based and

423 development-based values (e.g., Baffle Creek in Australia, Milford Sound in New Zealand, and

424 Whittier in Alaska), but in the absence of road access, there was greater prevalence of nature-

425 based ecosystem values.

427 Study Limitations

428 This comparative study brought together multiple primary and secondary data sources to 429 examine potential associations between coastal attributes and mapped ecosystem values. Given 
430 the complexity of the study, there were limitations that provide direction for future research.

431 Most important was the operational definition for the coastal zone. Our selection of distance

432 bands up to $3 \mathrm{~km}$ for analyses was heuristic to achieve comparability across diverse coastal study

433 areas. Alternative operational definitions for the coastal zone could have been used, for example,

434 a combination of both distance and elevation criteria. We chose not to use both distance and

435 elevation because this would have resulted in non-uniform coastal areas across the five mapping

436 studies, biasing the frequency distributions of the point data. However, future research could

437 explore alternative operational definitions for the coastal zone.

438 Another limitation was the lack of consistent global spatial data for comparative analysis.

439 The highest quality spatial data is typically generated and maintained by individual countries

440 such that intercountry comparison is constrained by consistency in data classification, spatial

441 resolution, and data quality. This spatial data limitation applies to both physical classification

442 (e.g., geomorphic features) as well as administrative classification (e.g., land tenure). As more

443 global data becomes available, additional spatial analyses can be completed.

444 Differences in sampling and data collection methods used in the five studies represent

445 another study limitation (see Table 1). The Malaysian mapping study used convenience sampling

446 while the other four studies used random household sampling. The New Zealand study had a

447 larger volunteer sampling component (6\% of sample size) than the other studies. Participant

448 domicile information was not consistently collected in the five studies limiting the ability to

449 conduct analyses to examine the potential confounding effect of distance from home location to

450 mapped coastal values. Future research should consistently collect home location data as part of

451 the participatory mapping process.

452 Finally, there was sampling response bias on the demographic variables of gender and 453 age, and where collected, formal level of education and income (see Table 1). This response bias

454 is consistent with the majority of reported PPGIS studies (Brown and Kyttä, 2014). Do

455 participant demographic characteristics influence the type and number of values mapped? The

456 available evidence is mixed. Brown and Reed (2009) reported that women mapped more of

457 certain types of landscape values than men (biological, life sustaining, and learning values) in

458 two out of three studies examined. On the variables of age and formal education, there were

459 small differences in the number of values mapped, but only for a few types of values. In this 
comparative study, the demographic response biases represent a study limitation, however, the biases were relatively small and importantly, consistent in all five countries examined.

\section{Conclusion}

There are currently a number of initiatives that aim to incorporate cultural ecosystem services in coastal planning (Arkema et al., 2015; Gould et al., 2015; Saunders et al., 2015). To aid this effort, this research sought to describe how cultural ecosystem values are generally distributed in coastal areas and to identify potential associations and patterns across diverse coastal features and human populations. As shown in this paper, cultural ecosystem values were disproportionately abundant in coastal zones in five diverse regions with the spatial distribution of values related to land cover/use and coastal access. An important question for coastal planning and management is the extent to which diverse ecosystem values should be spatially integrated or separated through coastal land use zoning. Intensive human development in coastal areas provides social benefit, but often at the expense of supporting and regulatory ecosystem services. Where natural forces dominate in the coastal zone, mapped cultural ecosystem values are less abundant resulting in fewer advocates for coastal protection from development pressure. The distribution of mapped ecosystem values can support the designation or modification of land use zones found in coastal management plans using a method called values compatibility analysis (Brown and Reed, 2012) that determines acceptable land uses based on their compatibility with mapped values. While the creation of zoning classifications and maps is often viewed as a technical expert planning activity, coastal planning can be enhanced through the integration of spatially-explicit cultural ecosystem values obtained through participatory mapping.

\section{Acknowledgements}

The authors acknowledge the contributions of Shannon Donovan, Lars Brabyn, Azadeh Karimi, and Amirul Zolkafli to the collection of participatory mapped data in the studies reported in this study. The authors also acknowledge the study participants who generously contributed their time and energy to help us understand what they value about the regions where they live. 


\section{References}

Agardy, T., Alder, J., Dayton, P., Curran, S., Kitchingman, A., Wilson, M., ... \& Saifullah, S. (2005). Coastal systems (Chapter 19). In Ecosystems and human well-being: Current state and trends, Vol. 1, 513-549. Available at: http://www.millenniumassessment.org/documents/document.288.aspx.pdf Accessed July 9, 2016.

Arkema, K. K., Verutes, G. M., Wood, S. A., Clarke-Samuels, C., Rosado, S., Canto, M., ... \& Faries, J. (2015). Embedding ecosystem services in coastal planning leads to better outcomes for people and nature. Proceedings of the National Academy of Sciences, 112(24), 7390-7395.

Barbier, E. B., Hacker, S. D., Kennedy, C., Koch, E. W., Stier, A. C., \& Silliman, B. R. (2011). The value of estuarine and coastal ecosystem services. Ecological Monographs, 81(2), 169-193.

Brenner, J., Jiménez, J. A., Sardá, R., \& Garola, A. (2010). An assessment of the non-market value of the ecosystem services provided by the Catalan coastal zone, Spain. Ocean \& Coastal Management, 53(1), 27-38.

Brown, G. (2013). The relationship between social values for ecosystem services and global land cover: An empirical analysis. Ecosystem Services, 5, 58-68.

Brown, G., \& Brabyn, L. (2012). An analysis of the relationships between multiple values and physical landscapes at a regional scale using public participation GIS and landscape character classification. Landscape and Urban Planning, 107(3),317-331.

Brown, G., \& Donovan, S. (2014). Measuring change in place values for environmental and natural resource planning using Public Participation GIS (PPGIS): Results and challenges for longitudinal research. Society \& Natural Resources, 27(1), 36-54.

Brown, G., \& Fagerholm, N. (2015). Empirical PPGIS/PGIS mapping of ecosystem services: A review and evaluation. Ecosystem Services, 13, 119-133.

Brown, G., \& Kyttä, M. (2014). Key issues and research priorities for public participation GIS (PPGIS): A synthesis based on empirical research. Applied Geography, 46,122-136.

Brown, G., Raymond, C. M., \& Corcoran, J. (2015a). Mapping and measuring place attachment. Applied Geography, 57, 42-53.

Brown, G., Hausner, V., and Lægreid, E. (2015b). Physical landscape associations with mapped ecosystem values with implications for spatial value transfer: An empirical study from Norway. Ecosystem Services, 15, 19-34. 
Brown, G., \& Raymond, C. (2014). Methods for identifying land use conflict potential using participatory mapping. Landscape and Urban Planning, 122, 196-208.

Brown, G., \& Reed, P. (2012). Values Compatibility Analysis: Integrating public values in a forest planning decision support system. Applied Spatial Analysis and Policy, 5(4), 317332.

Brown, G. \& Reed, P. (2009). Public Participation GIS: A new method for national forest planning. Forest Science 55(2), 166-182.

Brown, G., \& Weber, D. (2013). Using Public Participation GIS (PPGIS) on the Geoweb to monitor tourism development preferences. Journal of Sustainable Tourism, 21(2), 192211.

Carter, R.W.G., (1988). Coastal environments - an introduction to the physical, ecological and cultural systems of coastlines. Academic Press, London.

Chan, K. M., Guerry, A. D., Balvanera, P., Klain, S., Satterfield, T., Basurto, X., ... \& Woodside, U. (2012). Where are cultural and social in ecosystem services? A framework for constructive engagement. BioScience, 62(8), 744-756.

CIESIN. 2015. Gridded Population of the World (GPW), v4, UN-Adjusted Population Count for 2015. Center for International Earth Science Information Network. Columbia University. Available at: http://beta.sedac.ciesin.columbia.edu/data/set/gpw-v4-population-countadjusted-to-2015-unwpp-country-totals/data-download Accessed March 25, 2016.

COM. (2000). Commission of the European Communities. "On integrated coastal zone management: A strategy for Europe.” Available at: http://eurlex.europa.eu/LexUriServ/LexUriServ.do?uri=COM:2000:0547:FIN:EN:PDF Accessed March 17, 2016.

Daniel, T. C., Muhar, A., Arnberger, A., Aznar, O., Boyd, J. W., Chan, K. M., ... \& GrêtRegamey, A. (2012). Contributions of cultural services to the ecosystem services agenda. Proceedings of the National Academy of Sciences, 109(23), 8812-8819.

De Groot, R. S., Alkemade, R., Braat, L., Hein, L., \& Willemen, L. (2010). Challenges in integrating the concept of ecosystem services and values in landscape planning, management and decision making. Ecological Complexity, 7(3), 260-272.

De Vreese, R., Leys, M., Fontaine, C.M., \& Dendoncker, N. (2016). Social mapping of perceived ecosystem services supply - The role of social landscape metrics and social hotspots for integrated ecosystem services assessment, landscape planning and management. Ecological Indicators, 66, 517-533. 
Geoscience Australia. (2016). Geoscience Australia Web Services. Available at: http://www.ga.gov.au/data-pubs/web-services/ga-web-services Accessed March 11, 2016.

Gould, R. K., Klain, S. C., Ardoin, N. M., Satterfield, T., Woodside, U., Hannahs, N., ... \& Chan, K. M. (2015). A protocol for eliciting nonmaterial values through a cultural ecosystem services frame. Conservation Biology, 29(2), 575-586.

Hausner, V. H., Brown, G., \& Lægreid, E. (2015). Effects of land tenure and protected areas on ecosystem services and land use preferences in Norway. Land Use Policy, 49, 446-461.

Hazelwood, M., Nicholas, W.A. \& Woolf, M., 2012. National Coastal Geomorphology Information Framework: Discovery and Distribution. Record 2013/035. Geoscience Australia, Canberra.

Hernández-Morcillo, M., Plieninger, T., \& Bieling, C. (2013). An empirical review of cultural ecosystem service indicators. Ecological Indicators, 29, 434-444.

Karimi, A., Brown, G., and Hockings, M. (2015). Methods and participatory approaches for identifying social-ecological hotspots. Applied Geography, 63, 9-20.

Klain, S. C., \& Chan, K. M. (2012). Navigating coastal values: Participatory mapping of ecosystem services for spatial planning. Ecological Economics, 82, 104-113.

Lowery, D. R., \& Morse, W. C. (2013). A qualitative method for collecting spatial data on important places for recreation, livelihoods, and ecological meanings: Integrating focus groups with public participation geographic information systems. Society \& Natural Resources, 26(12), 1422-1437.

Martin, C. L., Momtaz, S., Gaston, T., \& Moltschaniwskyj, N. A. (2016). A systematic quantitative review of coastal and marine cultural ecosystem services: Current status and future research. Marine Policy, 74, 25-32.

MEA (Millennium Ecosystem Assesment), 2005. Ecosystems and Human Well-being: A Framework for Assessment. Island Press, Washington D.C.

Milcu, A. I., Hanspach, J., Abson, D., \& Fischer, J. (2013). Cultural ecosystem services: a literature review and prospects for future research. Ecology and Society, 18(3), 44.

Norton, L. R., Inwood, H., Crowe, A., \& Baker, A. (2012). Trialling a method to quantify the 'cultural services' of the English landscape using Countryside Survey data. Land Use Policy, 29(2), 449-455.

Plieninger, T., Dijks, S., Oteros-Rozas, E., \& Bieling, C. (2013). Assessing, mapping, and quantifying cultural ecosystem services at community level. Land Use Policy, 33, 118129. 
626

627

628

629

630

631

632

633

634

635

636

637

638

639

640

641

642

643

644

645

646

647

648

649

650

651

652

653

654

655

656

657

658

659

660

661

662

663

664
Queensland Government. (2015). Baseline roads and tracks Queensland. Available at: http://qldspatial.information.qld.gov.au/catalogue/custom/search.page?q=road+centreline \# Accessed April 1, 2016.

Raudsepp-Hearne, C., Peterson, G. D., \& Bennett, E. M. (2010). Ecosystem service bundles for analyzing tradeoffs in diverse landscapes. Proceedings of the National Academy of Sciences, 107(11), 5242-5247.

Rieprich, R., \& Schnegg, M. (2015). The value of landscapes in Northern Namibia: A system of intertwined material and nonmaterial services. Society \& Natural Resources, 28, 1-18.

Saunders, J., Beaumont, N., Atkins, J. P., Lannin, A., Lear, D., Ozdemiroglu, E., \& Potts, T. (2015). A Review of Marine and Coastal Ecosystem Services Data and Tools to Incorporate This into Decision-Making. In Coastal Zones Ecosystem Services (pp. 145164). Springer International Publishing.

Schaich, H., Bieling, C., \& Plieninger, T. (2010). Linking ecosystem services with cultural landscape research. Gaia-Ecological Perspectives for Science and Society, 19(4), 269277.

Turner, K. G., Odgaard, M. V., Bøcher, P. K., Dalgaard, T., \& Svenning, J. C. (2014). Bundling ecosystem services in Denmark: Trade-offs and synergies in a cultural landscape. Landscape and Urban Planning, 125, 89-104.

USGS. 2014. Coastal classification mapping project. Available at: http://coastal.er.usgs.gov/coastal-classification/class.html Accessed March 13, 2016.

UNEP. 2016. Cities and Coastal Areas. Available at: http://www.unep.org/urban_environment/issues/coastal_zones.asp Accessed July 9, 2016.

van Riper, C. J., \& Kyle, G. T. (2014). Capturing multiple values of ecosystem services shaped by environmental worldviews: A spatial analysis. Journal of Environmental Management, 145, 374-384.

Zolkafli, A., Liu, Y., \& Brown, G. (2017). Bridging the knowledge divide between public and experts using PGIS for land use planning in Malaysia. Applied Geography. In press. 
Table 1. Coastal studies with participatory mapping included in the analysis.

\begin{tabular}{|c|c|c|c|c|c|c|c|c|c|}
\hline Year & $\begin{array}{l}\text { Study } \\
\text { Location }\end{array}$ & Coastal setting & $\begin{array}{l}\text { Size of } \\
\text { study } \\
\text { area } \\
\left(\mathrm{km}^{2}\right)\end{array}$ & $\begin{array}{l}\text { Approx. } \\
\text { pop. } \\
\text { Density } \\
(\text { people } \\
\text { lkm²) }\end{array}$ & $\begin{array}{l}\text { Target population, } \\
\text { sampling method, } \\
\text { and response rate }\end{array}$ & $\begin{array}{l}\text { Sample } \\
\text { size }\end{array}$ & Sample characteristics & $\begin{array}{l}\text { Cultural (non-cultural) } \\
\text { ecosystem values mapped } \\
\text { in study }\end{array}$ & $\begin{array}{l}\text { Reference } \\
\text { describing } \\
\text { data } \\
\text { collection }\end{array}$ \\
\hline 2014 & $\begin{array}{l}\text { Norway } \\
\text { (Nordland } \\
\text { region) }\end{array}$ & Natural features & $\begin{array}{l}11,306 \\
\mathrm{~km}^{2}\end{array}$ & $7 / \mathrm{km}^{2}$ & $\begin{array}{l}\text { Households } \\
\text { (Random sample) } \\
14 \% \text { internet } \\
\text { response }\end{array}$ & 440 & $\begin{array}{l}\text { Mean age of participants } \\
49 \text { years with more males } \\
(57 \%), \text { higher levels of } \\
\text { formal education, and } \\
\text { higher mean income than } \\
\text { comparable census data. }\end{array}$ & $\begin{array}{l}\text { aesthetic/scenic, recreation, } \\
\text { economic, cultural, spiritual, } \\
\text { social, therapeutic } \\
\text { (hunting/fishing, pasture, } \\
\text { biological, clean water, } \\
\text { wild/pristine) }\end{array}$ & $\begin{array}{l}\text { Brown et al. } \\
(2015 b)\end{array}$ \\
\hline 2014 & $\begin{array}{l}\text { Australia } \\
\text { (Baffle Basin } \\
\text { region) }\end{array}$ & $\begin{array}{l}\text { Mix of natural } \\
\text { features and } \\
\text { rural } \\
\text { development }\end{array}$ & $\begin{array}{l}3,999 \\
\mathrm{~km}^{2}\end{array}$ & $1.5 / \mathrm{km}^{2}$ & $\begin{array}{l}\text { Households } \\
\text { (Random sample) } \\
12 \% \text { internet } \\
\text { response, } 45 \% \\
\text { hardcopy response }\end{array}$ & 264 & $\begin{array}{l}\text { Mean age of participants } \\
59 \text { years with more males } \\
(58 \%) \text { than comparable } \\
\text { census data. }\end{array}$ & $\begin{array}{l}\text { aesthetic/scenic, recreation, } \\
\text { economic, spiritual, } \\
\text { heritage/cultural, social, } \\
\text { learning, intrinsic/existence, } \\
\text { future/bequest, social } \\
\text { (biological, life sustaining ) }\end{array}$ & $\begin{array}{l}\text { Karimi et al. } \\
(2015)\end{array}$ \\
\hline 2014 & $\begin{array}{l}\text { Malaysia (State } \\
\text { of Perlis) }\end{array}$ & $\begin{array}{l}\text { Rural } \\
\text { development and } \\
\text { crop agriculture }\end{array}$ & $823 \mathrm{~km}^{2}$ & $300 / \mathrm{km}^{2}$ & $\begin{array}{l}\text { General public } \\
\text { convenience sample } \\
\text { (face-to-face } \\
\text { recruitment) with } \\
73 \% \text { participation }{ }^{1}\end{array}$ & 292 & $\begin{array}{l}\text { Median age of participants } \\
36 \text { years (higher than } \\
\text { census) with slightly more } \\
\text { male participation ( } 52 \%) \\
\text { than female. Non-Malay } \\
\text { ethnic groups ( } 10 \% \text { of } \\
\text { population) were under- } \\
\text { represented in sample. }\end{array}$ & $\begin{array}{l}\text { aesthetic/scenic, recreation, } \\
\text { economic, spiritual, heritage } \\
\text { (biological/nature, built } \\
\text { environment) }\end{array}$ & $\begin{array}{l}\text { Zolkafli et } \\
\text { al., (in } \\
\text { press) }\end{array}$ \\
\hline 2012 & $\begin{array}{l}\text { Alaska } \\
\text { (Chugach } \\
\text { National Forest) }\end{array}$ & Natural features & $\begin{array}{l}38,836 \\
\mathrm{~km}^{2}\end{array}$ & $<1 / \mathrm{km}^{2}$ & $\begin{array}{l}\text { Households } \\
\text { (Random sample) } \\
12 \% \text { internet } \\
\text { response }\end{array}$ & 244 & $\begin{array}{l}\text { Mean age of participants } \\
48 \text { years with more males } \\
(60 \%) \text { and higher levels of } \\
\text { formal education than } \\
\text { comparable census data. }\end{array}$ & $\begin{array}{l}\text { aesthetic/scenic, recreation, } \\
\text { economic, learning, historic, } \\
\text { cultural, spiritual therapeutic, } \\
\text { intrinsic (biological, life } \\
\text { sustaining, wilderness) }\end{array}$ & $\begin{array}{l}\text { Brown and } \\
\text { Donovan } \\
(2014)\end{array}$ \\
\hline 2011 & $\begin{array}{l}\text { New Zealand } \\
\text { (Southland } \\
\text { region) }\end{array}$ & $\begin{array}{l}\text { Mix of natural } \\
\text { features with } \\
\text { rural } \\
\text { development }\end{array}$ & $\begin{array}{l}34,438 \\
\mathrm{~km}^{2}\end{array}$ & $2.8 / \mathrm{km}^{2}$ & $\begin{array}{l}\text { Households, park } \\
\text { visitors, volunteers } \\
\text { Response rate not } \\
\text { provided }\end{array}$ & 268 & $\begin{array}{l}\text { Median age of participants } \\
48 \text { years with more males } \\
(62 \%) \text { and higher levels of } \\
\text { formal education that } \\
\text { comparable census data. }\end{array}$ & $\begin{array}{l}\text { aesthetic/scenic, recreation, } \\
\text { economic, historical/cultural, } \\
\text { social (native vegetation, } \\
\text { native wildlife, marine, life } \\
\text { sustaining, wilderness) }\end{array}$ & $\begin{array}{l}\text { Brown and } \\
\text { Brabyn } \\
(2012)\end{array}$ \\
\hline
\end{tabular}

${ }^{1}$ Convenience sample with effort to approximate general population gender proportion and age. Participation rate is number of face-to-face contacts less refusal. 
Table 2. Distribution of mapped ecosystem values in the coastal zone significantly positively or negatively associated with artificial areas (development) or agricultural land cover.

\begin{tabular}{|c|c|c|c|c|c|}
\hline $\begin{array}{l}\text { Study } \\
\text { Location }\end{array}$ & $\begin{array}{l}\text { Dominant } \\
\text { coastal land } \\
\text { use }\end{array}$ & $\begin{array}{l}\text { Coastal } \\
\text { zone }\end{array}$ & $\begin{array}{l}\% \text { of coastal zone in } \\
\text { artificial or agricultural } \\
\text { land cover(1) }\end{array}$ & $\begin{array}{l}\% \text { of all values } \\
\text { mapped located in } \\
\text { artificial or agricultural } \\
\text { land cover }\end{array}$ & $\begin{array}{l}\text { Significant positive or negative associations } \\
\text { (residuals) }\end{array}$ \\
\hline \multirow{4}{*}{ Norway } & Natural & & & & \\
\hline & & $1 \mathrm{~km}$ & $0.4 \%$ & $2.0 \%$ & Economic (+2.0) Social (+4.3) Therapeutic (+3.2) \\
\hline & & $2 \mathrm{~km}$ & $0.3 \%$ & $1.4 \%$ & Economic $(+2.5)$ Social $(+4.1)$ Therapeutic $(+3.9)$ \\
\hline & & $3 \mathrm{~km}$ & $0.2 \%$ & $1.2 \%$ & Economic $(+2.7)$ Social $(+5.2)$ Therapeutic $(+3.2)$ \\
\hline \multirow{4}{*}{ Australia } & & $500 \mathrm{~m}$ & $3.5 \%$ & $10.6 \%$ & Economic $(+4.1)$ Social $(+3.3)$ \\
\hline & & $1 \mathrm{~km}$ & $3.1 \%$ & $9.2 \%$ & Economic (+4.9) Social (+3.4) Biological (-2.1) \\
\hline & & $2 \mathrm{~km}$ & $5.1 \%$ & $9.0 \%$ & Economic (+6.6) Social $(+3.7)$ Biological $(-2.6)$ \\
\hline & & $3 \mathrm{~km}$ & $6.6 \%$ & $8.4 \%$ & Economic (+6.9) Social (+4.3) Biological $(-2.7)$ \\
\hline \multirow[t]{3}{*}{ Malaysia } & Agriculture & & & & \\
\hline & & $500 \mathrm{~m}$ & $100 \%$ & $100 \%$ & $\mathrm{~N} / \mathrm{A}(3)$ \\
\hline & & $1 \mathrm{~km}$ & $100 \%$ & $100 \%$ & $\mathrm{~N} / \mathrm{A}$ \\
\hline \multirow{3}{*}{ Alaska } & & $1 \mathrm{~km}$ & $0.0 \%$ & $0.0 \%$ & $\mathrm{~N} / \mathrm{A}$ \\
\hline & & $2 \mathrm{~km}$ & $0.0 \%$ & $0.0 \%$ & $\mathrm{~N} / \mathrm{A}$ \\
\hline & & $3 \mathrm{~km}$ & $0.0 \%$ & $0.0 \%$ & N/A \\
\hline \multirow[t]{5}{*}{$\begin{array}{l}\text { New } \\
\text { Zealand }\end{array}$} & $\begin{array}{l}\text { Mix (natural \& } \\
\text { agriculture) }\end{array}$ & & & & \\
\hline & & $500 \mathrm{~m}$ & $12.0 \%$ & $16.9 \%$ & $\mathrm{~N} / \mathrm{S}(2)$ \\
\hline & & $1 \mathrm{~km}$ & $15.7 \%$ & $16.4 \%$ & $\mathrm{~N} / \mathrm{S}(2)$ \\
\hline & & $2 \mathrm{~km}$ & $17.5 \%$ & $15.8 \%$ & None \\
\hline & & $3 \mathrm{~km}$ & $18.0 \%$ & $15.0 \%$ & Life sustaining $(-2.0)$ \\
\hline
\end{tabular}

(1) terrestrial areas only; excludes areas identified as water in land cover

(2) chi-square test not significant; residuals not meaningful

(3) nearly all values associated with artificial features (agriculture)

(4) all values associated with natural features 
Page 23 of 29

Table 3. Proportion of ecosystem values falling within increasing distance bands from coastline by country. Statistically significant different proportions $(p<0.05$ ) are indicated by different colors except as indicated by superscript letter that denote studies whose proportions do not differ significantly from each other.

\begin{tabular}{|c|c|c|c|c|c|c|c|c|}
\hline Value & $\begin{array}{l}\text { Distance } \\
\text { Band }\end{array}$ & Alaska & Australia & Malaysia & $\begin{array}{l}\text { New } \\
\text { Zealand }\end{array}$ & Norway & Most similar & Most different \\
\hline \multicolumn{9}{|c|}{ Aesthetic } \\
\hline & $500 \mathrm{~m}$ & $29.8 \%$ & $60.5 \%$ & $43.4 \%$ & $23.5 \%$ & $27.1 \%$ & Alaska, Malaysia, & Australia, New \\
\hline & $1 \mathrm{~km}$ & $40.0 \%$ & $68.1 \%$ & $44.4 \%$ & $29.0 \%{ }^{a}$ & $35.6 \%{ }^{\mathrm{a}}$ & Norway & Zealand \\
\hline & $2 \mathrm{~km}$ & $46.6 \%$ & $72.6 \%$ & $50.5 \%$ & $33.1 \%$ & $47.0 \%$ & & \\
\hline & $3 \mathrm{~km}$ & $49.8 \%$ & $73.8 \%$ & $53.2 \%$ & $34.7 \%$ & $54.4 \%$ & & \\
\hline \multicolumn{9}{|c|}{ Recreation } \\
\hline & $500 \mathrm{~m}$ & $21.0 \%$ & $55.2 \%$ & $21.9 \%$ & $12.5 \%$ & $13.8 \%$ & Alaska, Malaysia, & Australia, New \\
\hline & $1 \mathrm{~km}$ & $28.8 \%^{a}$ & $61.1 \%$ & $21.9 \% \%^{a, b, c}$ & $15.3 \%{ }^{c}$ & $21.7 \%^{b}$ & Norway & Zealand \\
\hline & $2 \mathrm{~km}$ & $35.1 \%$ & $64.9 \%$ & $37.7 \%$ & $19.4 \%$ & $37.2 \%$ & & \\
\hline & $3 \mathrm{~km}$ & $37.7 \%$ & $68.0 \%$ & $38.3 \%$ & $22.1 \%$ & $48.3 \%$ & & \\
\hline \multicolumn{9}{|c|}{ Economic } \\
\hline & $500 \mathrm{~m}$ & $28.1 \%$ & $28.3 \% \%^{a, b}$ & $18.6 \%^{b}$ & $31.1 \%$ & $42.3 \% \%^{a}$ & Alaska, Australia, & Malaysia \\
\hline & $1 \mathrm{~km}$ & $40.7 \%$ & $42.5 \%$ & $19.0 \%$ & $37.8 \%$ & $49.5 \%$ & New Zealand, & \\
\hline & $2 \mathrm{~km}$ & $54.4 \%$ & $49.6 \%$ & $19.8 \%$ & $37.8 \%$ & $54.4 \%$ & Norway & \\
\hline & $3 \mathrm{~km}$ & $58.9 \%$ & $50.4 \%^{a}$ & $22.0 \%$ & $40.5 \%^{\mathrm{a}}$ & $59.3 \%^{a}$ & & \\
\hline \multicolumn{9}{|c|}{ Biological } \\
\hline & $500 \mathrm{~m}$ & $25.2 \%$ & $36.0 \%$ & $8.6 \%$ & & $20.3 \%$ & Alaska, Norway & Australia, \\
\hline & $1 \mathrm{~km}$ & $38.8 \%$ & $49.1 \%$ & $8.6 \%$ & & $28.0 \%$ & & Malaysia \\
\hline & $2 \mathrm{~km}$ & $49.2 \%{ }^{a}$ & $58.3 \%{ }^{\mathrm{a}}$ & $25.0 \%$ & & $38.1 \%$ & & \\
\hline & $3 \mathrm{~km}$ & $52.6 \%^{a}$ & $63.6 \%{ }^{a}$ & $33.2 \%^{\mathrm{b}}$ & & $43.2 \%^{\mathrm{b}}$ & & \\
\hline \multicolumn{9}{|c|}{ Life sustaining } \\
\hline & $500 \mathrm{~m}$ & $18.1 \%$ & $32.8 \%$ & & $6.3 \%$ & & & Alaska, Australia, \\
\hline & $1 \mathrm{~km}$ & $24.6 \%$ & $41.7 \%$ & & $9.3 \%$ & & & New Zealand \\
\hline & $2 \mathrm{~km}$ & $33.2 \%$ & $49.1 \%$ & & $15.6 \%$ & & & \\
\hline & $3 \mathrm{~km}$ & $38.7 \%$ & $54.8 \%$ & & $17.6 \%$ & & & \\
\hline \multicolumn{9}{|c|}{ Historic } \\
\hline & $500 \mathrm{~m}$ & $46.8 \%$ & $45.4 \%$ & & $34.9 \%$ & $39.9 \%$ & Alaska, Australia, & \\
\hline & $1 \mathrm{~km}$ & $55.7 \%$ & $51.3 \%$ & & $39.7 \%$ & $48.6 \%$ & New Zealand, & \\
\hline & $2 \mathrm{~km}$ & $64.6 \%$ & $60.5 \%$ & & $46.6 \%$ & $53.1 \%$ & Norway & \\
\hline & $3 \mathrm{~km}$ & $64.6 \%{ }^{b}$ & $64.5 \%$ & & $49.3 \%^{a, b}$ & $54.5 \%^{a}$ & & \\
\hline \multicolumn{9}{|c|}{ Spiritual } \\
\hline & $500 \mathrm{~m}$ & $32.2 \%$ & $48.1 \%$ & $14.0 \%$ & & $42.5 \%$ & Alaska, Australia, & Malaysia \\
\hline & $1 \mathrm{~km}$ & $43.3 \%$ & $57.0 \%$ & $15.1 \%$ & & $51.2 \%$ & Norway & \\
\hline & $2 \mathrm{~km}$ & $52.0 \%$ & $62.0 \%$ & $16.3 \%$ & & $53.8 \%$ & & \\
\hline & $3 \mathrm{~km}$ & $54.4 \%$ & $64.6 \%$ & $17.4 \%$ & & $56.3 \%$ & & \\
\hline
\end{tabular}


Page $\mathbf{2 4}$ of $\mathbf{2 9}$

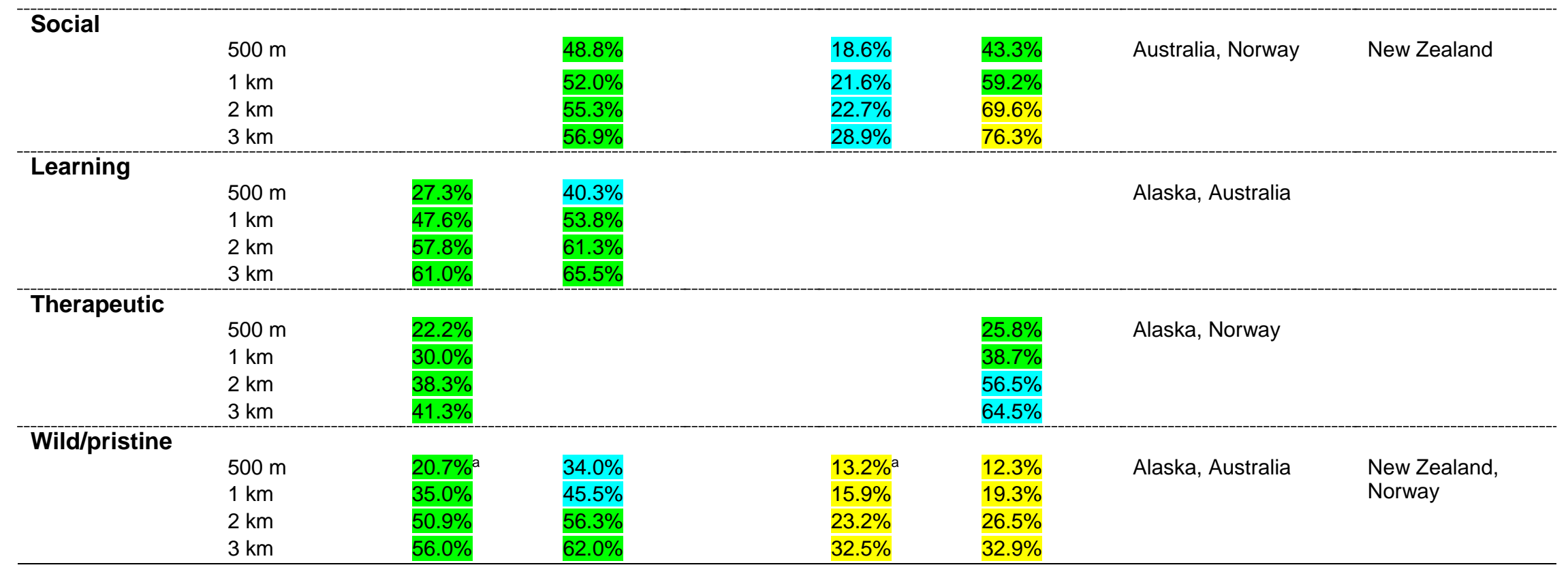


Figure 1. Location of study areas with the definition of coastal zones used to compare coastal and non-coastal zones.

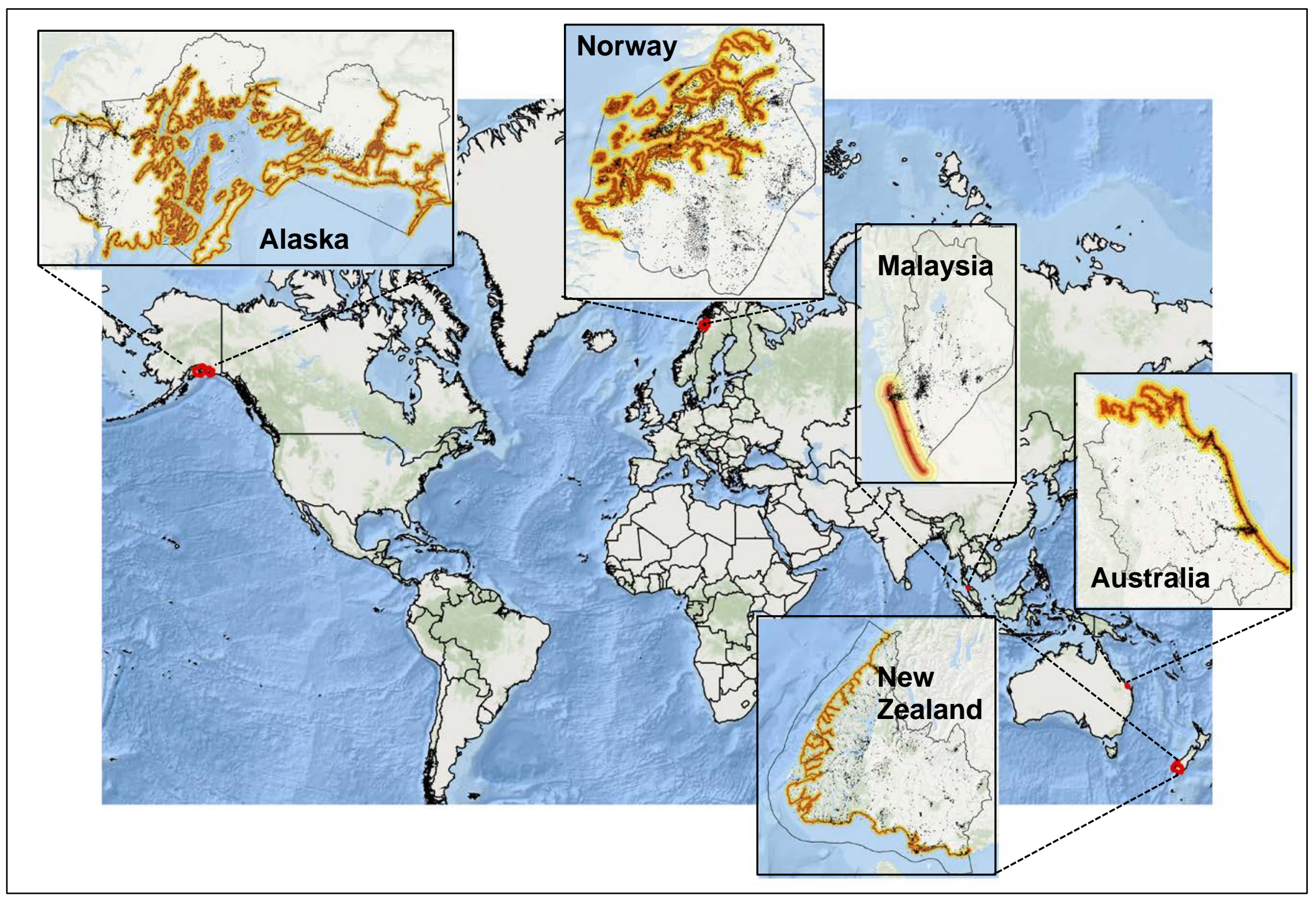


Figure 2. The percent of total mapped ecosystem values in the coastal zone for five study areas in (a) Norway, (b) Alaska, (c) New Zealand, (d) Malaysia, and (e) Australia found within four distance bands (500, 1000, 2000, and $3000 \mathrm{~m}$ ) from the coastline. In all countries, the observed distribution of ecosystem values exceeds the expected distribution of values based on areal or population proportions.

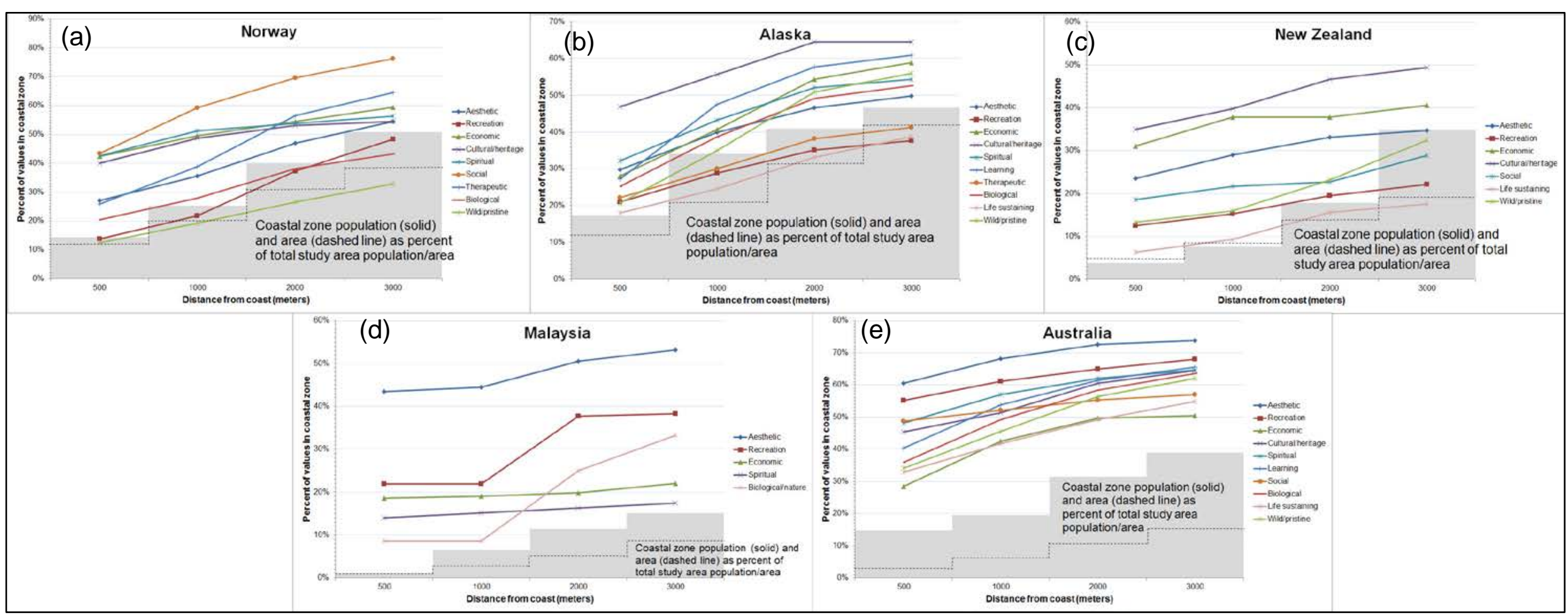


Figure 3. Plot of $\mathrm{z}$ scores measuring the deviation between the observed, mapped proportions of ecosystem values within a 1000 meter coastal zone and the expected proportion based on size of coastal zone area as a proportion of total study area size. Z scores greater than +2.0 (dashed line) indicate significant deviation from expected proportion of values.

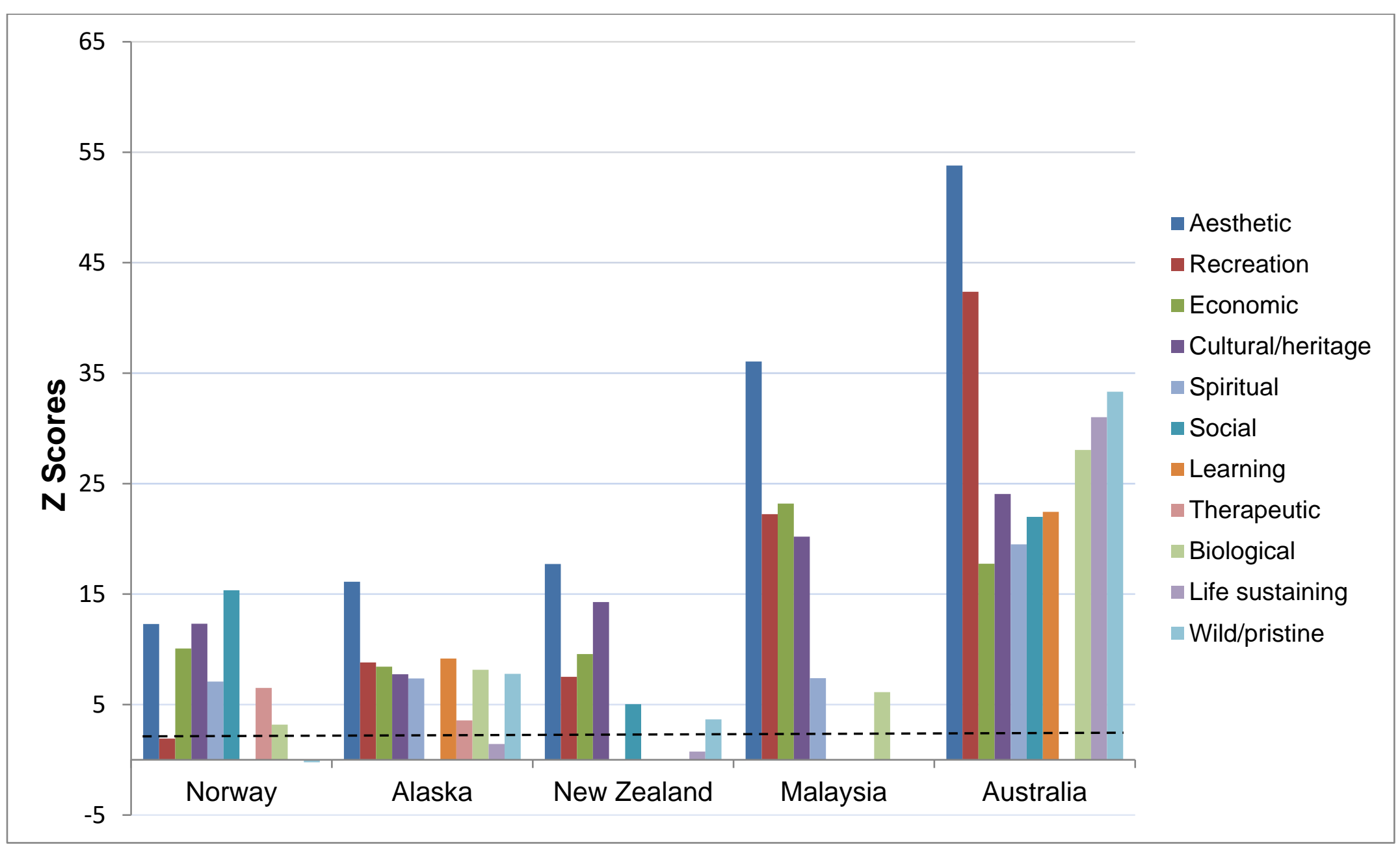


Figure 4. Plot of chi-square residual scores that measure the strength of the difference between observed and expected counts of ecosystem values in the coastal zone (1000 meters). Chi-square residual scores greater than +2.0 or less than -2.0 (dashed lines) indicate significant deviation from expected counts.

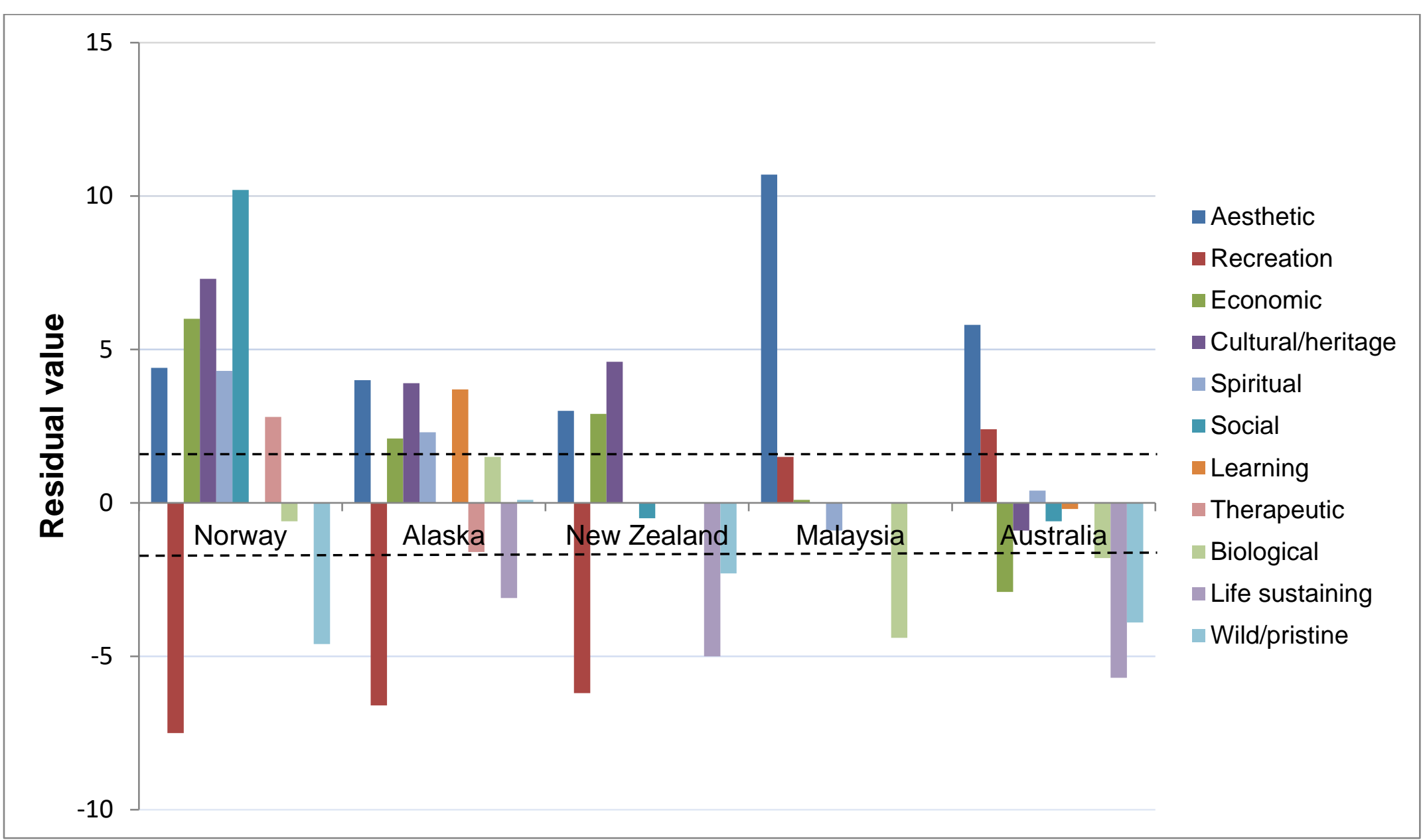


Figure 5. Distribution of ecosystem values associated with development/access (red) and natural areas (green).

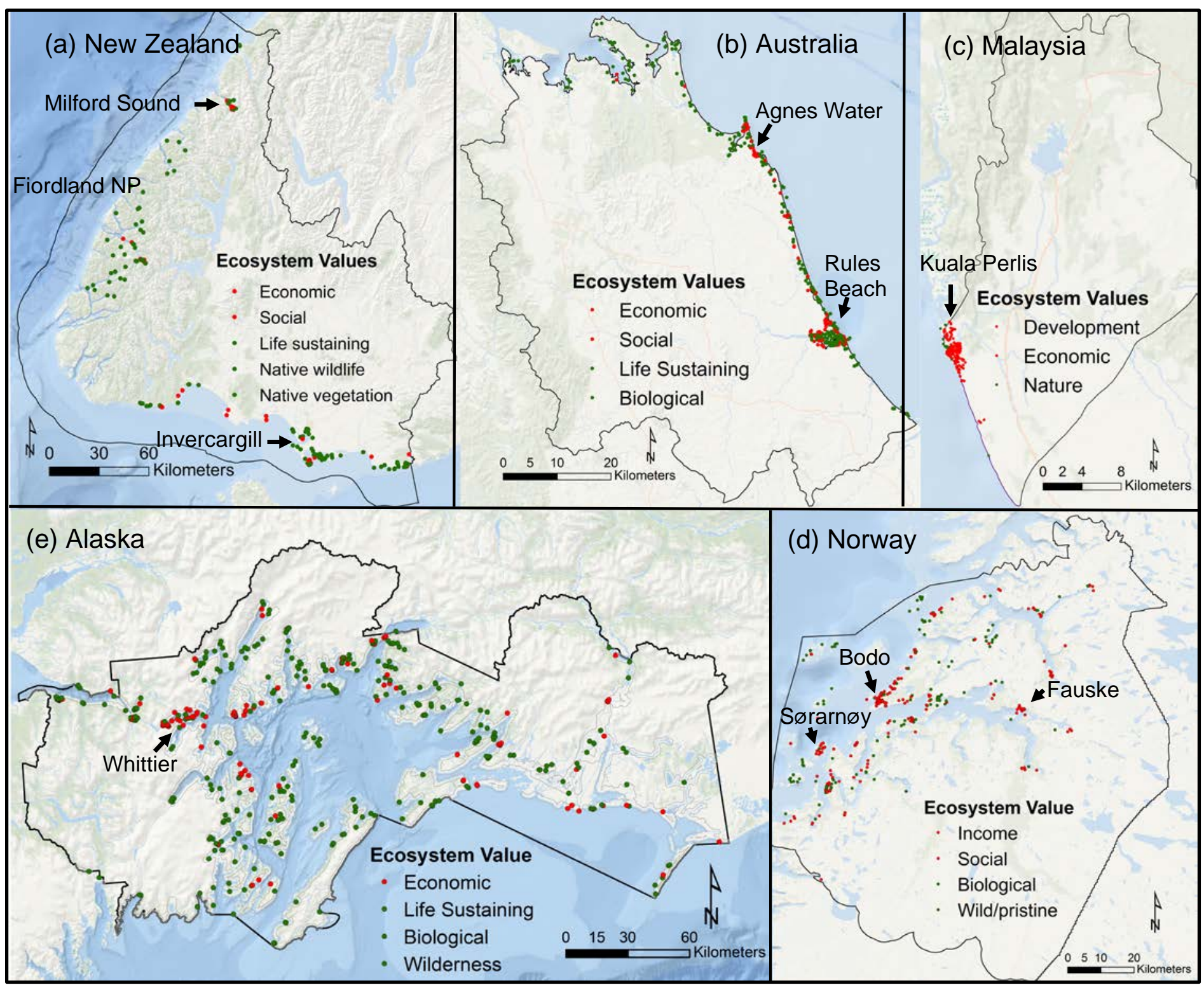

